\title{
Estudos críticos em Psicologia da leitura: Livro e experiência de ler
}

Luciana Dadico. Universidade de São Paulo.

\section{Resumo}

Este artigo expõe resultados de uma pesquisa sobre a experiência de leitura de livros no contexto da terceira revolução da leitura no Brasil. Foram realizadas entrevistas semiabertas e registradas com um gravador com duas leitoras adultas, voluntárias e residentes no estado de São Paulo. As imagens expressas nos relatos destas leitoras foram analisadas, permitindo identificar modos característicos de leitura do livro: a) fome de ler; b) modo intensivo; c) identificação subjetiva; d) leitura distraída; e) ponto de fuga; f) leitura conteudística; g) leitura interrompida; h) leitura atomística. Discutimos como estes modos de ler livros dialogam com as categorias imanentes do livro e com a experiência dos leitores. Espera-se que este trabalho possa oferecer um pequeno retrato dos modos de se ler livros no Brasil, contribuindo para identificar transformações culturais em curso e para a instituição de um campo de estudos críticos em Psicologia da Leitura.

Palavras-chave: leitura; experiência; livro; teoria crítica.

\begin{abstract}
Critical studies on psychology of reading: Books and the reading experience. This article presents results of a survey on the experience of reading books in the context of the third revolution of reading in Brazil. The research involved interviews with two adult readers. These interviews were conducted in half-open and tape-recorded way. Images expressed in the readers reports were analyzed, revealing characteristic ways of reading books: a) hungry to read; b) intensive reading; c) subjective identification; d) distracted reading; e) vanishing point; f) contentistic reading; g) interrupted reading; h) atomistic reading. We discuss how such ways of reading books dialogue with the immanent categories of books and with the experience of readers. We expect offering through this paper a small picture of the ways of reading books in Brazil, helping to identify ongoing cultural changes in this area. Besides, we expect to contribute to establish a field of critical studies in Psychology of Reading.
\end{abstract}

Keywords: reading; experience; book; critical theory.

\section{Resumen}

Estudios críticos en la psicología de la lectura: Libro y experiencia de leer. Este artículo presenta los resultados de una encuesta sobre la experiencia de lectura de libros en contexto de una tercera revolución de la lectura en Brasil. Se realizaron entrevistas con dos lectoras adultas, semiabiertas y grabadas con una grabadora. Dos informes se describen en este artículo. Las imágenes expresadas en los informes de las lectoras fueron analizadas, lo que permitió revelar modos característicos de la lectura de libros: a) hambre de leer; b) lectura intensiva; c) identificación subjetiva; d) lectura distraída; e) punto de fuga; f) lectura contenidística; g) lectura interrumpida; $\mathrm{h}$ ) lectura atomística. Se discute cómo estas formas de leer libros conversan con las categorías inmanentes de libros y con la experiencia de los lectores. Se espera que este trabajo pueda ofrecer una pequeña imagen de las maneras de leer libros en Brasil, ayudando a identificar los cambios culturales en curso y hacia el establecimiento de un campo de estudios críticos en Psicología de la Lectura.

Palabras clave: lectura; experiencia; libro; teoría crítica. 
O livro como objeto, suporte para o texto e mediador, dentre outros, da experiência estética literária, participou de transformações culturais decisivas para o advento da era moderna no mundo ocidental. A difusão do livro influenciou a forma como aprendemos a ler, a pensar, a compreender a sociedade, a história, a olhar para nós mesmos.

Paralelamente ao surgimento e às mudanças na forma do livro ao longo da história, diferentes modos de ler livros seguem entrelaçando-se de maneira decisiva às diversas facetas de nossa formação cultural. Do ponto de vista da Psicologia, basta dizer que o modo mais difuso de leitura que encontramos atualmente, individual e silencioso, exerceu grande contribuição para a constituição e o delineamento de uma subjetividade que se tornaria objeto de estudo da disciplina como ciência a partir do século XIX (Dadico, 2011).

O processo crescente de digitalização do livro e da literatura verificado nos dias de hoje, somado à importância da leitura do livro para formação do indivíduo e para o desenvolvimento subjetivo, motivou-nos a perguntar: como lemos livros hoje? Com o intuito de responder a essa questão, empreendemos uma pesquisa concluída no ano de 2011.

O primeiro objetivo da pesquisa (cujos resultados correspondentes já foram publicados) era descobrir como o livro enquanto objeto era percebido pelas leitoras. O segundo objetivo - exposto neste artigo - era descobrir como os livros em papel são lidos. Como questões secundárias, importava saber como os modos de ler descritos articulam-se à experiência dos leitores, e como a percepção do livro como objeto participa na configuração destes modos de leitura.

Com relação a esta última questão em particular, é necessário ressaltar que não se supõe uma relação de causalidade direta entre o medium que oferece suporte à obra literária e os modos de lê-la - embora as características imanentes do objeto ofereçam possibilidades e limites para seu uso. Conforme esclarecemos ao longo deste artigo, a relação entre leitor, obra literária e medium é histórica e culturalmente localizada, partícipe de certa estrutura de experiência (Benjamin, 1994) cuja conformação é influenciada pelos diversos objetos da cultura - incluindo os meios de comunicação e o próprio livro - ao mesmo tempo em que esta experiência contribui para moldar os usos destes objetos.

Espera-se que o presente estudo ajude a compreender este fenômeno complexo e multideterminado que é a experiência de leitura de livros em nosso país no momento presente, oferecendo informações capazes de auxiliar tanto psicólogos e educadores quanto aqueles interessados em comunicação, leitura e literatura.

Espera-se ainda que os resultados desta pesquisa, realizada junto a leitores de livros em papel, possam fornecer um pequeno retrato qualitativo do modo de ler livros no Brasil, que torne possível a realização, em um futuro breve, de estudos comparativos entre a leitura de livros e a leitura de livros em outros meios, incrementando a análise sobre a participação dos meios digitais na experiência de leitura (estamos atualmente realizando uma pesquisa nessa direção).

\section{A pesquisa}

A pesquisa aqui apresentada incluiu duas entrevistas semiabertas, sem uso de questionário e registradas em um gravador, seguindo as orientações de Queiróz (1983). Foram entrevistadas individualmente duas leitoras adultas, voluntárias, com idade de 36 e 74 anos, residentes no estado de São Paulo e com formação superior. Em um primeiro encontro, as leitoras discorreram livremente sobre os temas "livros" e "leitura" e, em seguida, escolheram um título para ser discutido conosco durante o segundo encontro. A exposição dos objetivos foi realizada nos primeiros encontros, ocasião em que também era solicitado à leitora que assinasse um termo de consentimento livre e esclarecido ${ }^{1}$. O sigilo foi assegurado para todas as fases de pesquisa (neste texto, utilizamos nomes inventados). As entrevistas ocorreram em ambientes reservados e duraram entre cinquenta minutos e duas horas.

Nossas entrevistas não eram terapêuticas - pois seu objetivo final era alheio às necessidades psíquicas do entrevistado - mas sugestões de Bleger (2011) sobre técnicas de entrevista nos foram úteis. A entrevista aberta permitia ao entrevistado exercer certo controle sobre o tempo e encadeamento dos assuntos. Esse controle do sujeito sobre o "campo" da entrevista ajuda a promover um ambiente de relaxamento e a redução das defesas psíquicas. Sendo impossível eliminar a ansiedade (que constitui o próprio motor da entrevista), na medida em que o entrevistado dirige a entrevista e o entrevistador a controla, a ansiedade pode ser regulada por meio do timing, em função dos objetivos da entrevista.

A análise do material foi realizada por meio de escutas repetidas, de modo a evitar as distorções de expressão e sentido envolvidas na transcrição de uma linguagem oral para a forma escrita. Os resultados foram sistematizados em função das imagens expressas na fala 
dos entrevistados que correspondiam aos objetos de interesse de nossa pesquisa. Estas imagens foram divididas em "imagens do livro", "imagens do livro-texto" e "imagens no texto, ou experiências de leitura".

A análise focada nas imagens expressas pelas leitoras em suas falas, em detrimento de uma análise de conteúdo de entrevistas transcritas, visava preservar a integridade forma-conteúdo [Gehalt $]^{2}$ do que nos foi comunicado. Em uma perspectiva teórico-crítica da sociedade, o sacrifício das formas decorrente de uma leitura de conteúdo teria concorrido para uma indesejável fragmentação e fetichização da linguagem, ora extirpada do conteúdo social sedimentado em suas formas. Formas nutridas, a seu turno, por imagens da experiência expressas na linguagem (Benjamin, 1994). Entendemos que a atenção às imagens construídas pelas leitoras dota estas imagens do poder de apresentarem a si mesmas. Por essa mesma razão, buscamos manter neste artigo as categorias que nasceram da leitura destas imagens tão próximas o quanto possível do contexto narrativo no qual foram engendradas.

Atendendo ao primeiro objetivo da pesquisa, cada conjunto de imagens foi analisado com vistas a compor uma fisiognomia do livro, descrito em função de suas características temporais e espaciais. Em seguida, debruçamo-nos sobre as imagens relacionadas aos modos de ler e às experiências individuais de leitura, ressignificadas à luz da compreensão obtida com a sistematização das categorias do livro. Os conjuntos de "imagens do livro" construídas pelas leitoras foram reunidos sob a alcunha de: a) bibliotecas; b) ambientes do livro e "ambiente livro"; c) compartilhar livros; tempos da leitura. As imagens do "livro-texto", por sua vez, foram agrupadas sob os títulos: a) fome de ler; b) modo intensivo: releituras e controle da percepção; c) encontrar-se na obra: identificação; d) leitura distraída e (des)obediência ao texto; e) ler livros: desenvolvimento ou embotamento? Um terceiro conjunto de imagens, particulares a cada leitura, fruto da relação individual da leitora com o livro lido, foram analisadas enquanto "imagens no texto: experiências de leituras". As categorias que identificam os modos de ler presentes nas entrevistas referem-se sobretudo ao segundo grupo de imagens, aquelas do livro-texto, embora estas dialogassem constantemente com as imagens descritas nos demais conjuntos.

O retorno continuado ao material, em diversos momentos da pesquisa e com diferentes níveis de profundidade, favoreceu a análise das imagens trazidas pelas leitoras, permitindo compreender melhor o modo como nossos leitores têm lido livros. Como resultado extraordinário e relevante desta pesquisa, pudemos verificar de que maneira a leitura mediada pelo livro possibilitou uma reorganização da experiência das leitoras.

\section{As revoluções da leitura, sua crise e o contexto brasileiro}

As condições econômicas, técnicas e culturais do Renascimento, no século XIV, geraram a necessidade de um sistema capaz de facilitar a reprodução de livros. Para que isso fosse possível, mais do que os tipos metálicos de Gutenberg, era preciso encontrar um material capaz de absorver a tinta impressa dos tipos. A fabricação de papel em larga escala, barateando o custo de produção do livro, exerceu impacto relevante para possibilitar a mecanização e a difusão do livro no século XV. Com o aumento na capacidade de produção do livro que as invenções do papel e da imprensa propiciaram, os hábitos de leitura assistiram à sua primeira revolução: cresceu a quantidade de leitores no mundo ocidental e consolidou-se um conjunto de modos de ler no qual a palavra oral e o texto se descolavam, propiciando uma leitura mais veloz, que exigia menos da memória do leitor. A leitura antes feita em voz alta, mesmo dentro das bibliotecas, passa a acontecer em silêncio, de forma mais privada e individual (Cavallo \& Chartier, 1995).

Ao contrário de McLuhan, que vincula as transformações culturais verificadas naquela época à invenção da imprensa, os historiadores da cultura sustentam que este foi apenas um dos fatores que, aliado a um conjunto de condições novas de alfabetização e relações culturalmente estabelecidas com o escrito, colaboraram para a conformação, a partir do século XV, de um modo de ler intensivo: isto é, de uma leitura comunitária e respeitosa, de pequena quantidade de livros, dentro de um cânone coletivo, com uso profundo do texto, lido repetidas vezes, com trechos memorizados e transmitidos entre gerações. O modo intensivo de leitura, característico deste período, ocorrerá mesmo no século XVIII, momento em que se processa uma segunda revolução da leitura ou Leserevolution (Engelsing citado por Darnton, 2011), e até os dias de hoje, como veremos adiante.

Sob o compasso das máquinas rotativas, a Leserevolution será marcada pela passagem de um modelo de leitura intensivo para um extensivo, típico da modernidade. A leitura extensiva nasce dentro de uma cultura mais individualista, com acesso a maior quantidade de livros e materiais diversos, lidos privadamente, 
para informação e entretenimento e de um novo lugar político postulado pela burguesia perante as rígidas estruturas sociais estabelecidas. Paulatinamente, os processos de recepção na época passaram por uma ampla modernização, no qual as raízes racionalistas do projeto iluminista serão substituídas por outras, de natureza empática e "emotiva". A recepção de Goethe na Alemanha provocou ondas de suicídio como resposta a Os sofrimentos do jovem Werther. A apreciação estética submetia-se ao entrelaçamento do mundo da leitura com a realidade cotidiana. A Lesewut, ou "raiva ao ler", característica do primeiro romantismo alemão (Cavallo \& Chartier, 1995), torna-se modelo de leitura extensiva: o leitor consome grande quantidade de livros, com avidez e velocidade, sem padrão metodológico rígido ou "respeito" pelo escrito. Com o tempo, esta leitura assumirá as características de uma recepção tranquila: o corpo dobrando-se ao instrumento, a leitura selvagem disciplinada.

Após o ano de 1760, as vendas de livros crescem exponencialmente na Europa; o romance, quatro vezes. O leitor de maior poder aquisitivo passa a exigir edições bem cuidadas. Volumes de bolso circulam poesia, sátira, almanaques. Paris, em 1824, contava com 47 mil assinantes de jornal, número que subiria para 200 mil apenas dois anos depois. Um dos sustentáculos deste aumento na França (e também no Brasil) foi a queda no preço das assinaturas, propiciada pela combinação entre a venda de espaço para réclames e o romance-folhetim.

Se a unidade entre escrita e leitura já fora destruída, paradoxalmente, junto com a maior difusão e o avanço das técnicas de reprodução do escrito, o salto técnico verificado desde o século XVIII até o advento dos meios de comunicação de massa promoveria novas e significativas alterações para a produção e a recepção literária. Algumas destas alterações aparecem refletidas na forma do romance como gênero literário.

Nos romances, a "imitação séria" do cotidiano afirma-se então como estilo entre a elevação aristocrática do trágico e o rebaixamento plebeu do cômico, adequada à apresentação literária da burguesia, estrato intermediário entre a aristocracia e a plebe. O romance ganha mais páginas, pois o público burguês, que dispunha de acesso econômico ao livro, passa a dispor de tempo livre, agora ocupado em seu consumo como artigo de entretenimento (Moretti, 2003).

Do ponto de vista formal, o discurso indireto livre e o efeito de invisibilidade do narrador tornarão o romance "comparável ao palco italiano burguês, do qual são removidas as cortinas para que o leitor participe dos acontecimentos como se estivesse presente" (Adorno, 2003, p. 60), reforçando intenções objetivistas de registro do real, possíveis desde o advento da fotografia. A recepção da literatura, por sua vez, seria afetada por um uso diferenciado da visão e por uma nova concepção de imagem, criando expectativas diversas frente aos padrões visuais que ora se instituíam.

Atualmente, uma terceira revolução da leitura (Cavallo \& Chartier, 1995) corresponde a renovadas formas de difusão do livro-texto. Pesquisadores têm se mostrado preocupados com os riscos que as novas tecnologias representam para a conservação de textos e o impacto cultural e educacional dessas mudanças. Teme-se que esta "revolução" signifique, na verdade, uma "crise" da leitura (favorecida pela incerteza vivida pela indústria editorial e pela desescolarização da população em todo o mundo), colaborando para o declínio do livro e de seu uso.

No Brasil, a terceira revolução da leitura desponta ao mesmo tempo em que se busca reverter um quadro histórico de fracasso escolar que resulta de e em uma grande dificuldade de acesso ao livro. A leitura no Brasil nunca alcançou patamares elevados. No Brasil Colônia não existiam universidades. As poucas escolas destinavam-se apenas à catequização de índios, à formação de clérigos, professores ou burocratas. O acesso ao livro, importado, era rigidamente controlado pela censura oficial. A imprensa só chegou legalmente em terras brasileiras com a comitiva de Dom João VI, durante a apressada fuga que antecedeu a invasão napoleônica a Portugal. Antes disso, a introdução de prelos no país fora duramente coibida (o tipógrafo carioca Isidoro da Fonseca encontraria seu destino num auto-de-fé, com o corpo garroteado e queimado numa praça pública de Lisboa, em 1739). Mesmo após a vinda da família real portuguesa para o país, o Correio Braziliense era editado em Londres e de lá contrabandeado para o Brasil. Apenas em 1821 o país se livraria da censura prévia, conhecendo sua primeira editora independente (Hallewell, 2005). Desde a independência, porém, o país parece não ter expurgado a ideia de que a manutenção dos baixos índices de escolaridade e acesso ao livro constituem instrumento válido de controle da população.

A política governamental de fomento do livro que seguiria à expansão da rede de ensino no período republicano fez-se acompanhar de um poderoso aparato repressivo. Após o golpe de 1964, o governo federal passou a subvencionar diretamente o setor livreiro, 
especialmente a produção de livros didáticos. Com a mesma mão, em 1970 era reinstituída a censura prévia de livros. Concomitantemente, o projeto de democratização do ensino naufragava na tentativa de ampliar o acesso à escola a um mínimo custo, com índices alarmantes de evasão e reprovação.

A despeito da inclusão quantitativa da população em idade escolar, alcançada sobretudo com a implantação de políticas de promoção automática na educação básica, nos anos 1990, o Brasil ainda conta com cerca de 13,4 milhões de analfabetos absolutos ( $8,7 \%$ da população) e 27,8 milhões de brasileiros de 15 anos ou mais com menos de quatro anos de estudo ${ }^{3}(18,3 \%)$ - perfazendo uma taxa de analfabetismo de $27 \%$ (Instituto Brasileiro de Geografia e Estatística [IBGE], 2012).

A última edição da pesquisa Retratos da leitura no Brasil (Instituto Pró-Livro, 2012), mostra que não somente há uma relação direta entre a quantidade de livros lidos e os anos de escolarização do leitor, mas que grande parte da leitura no país começa e termina no livro didático. Enquanto apenas metade dos entrevistados declarou ter lido ao menos um livro nos últimos três meses ${ }^{4}, 17,5 \%$ da população tinha lido um livro não confessional de modo espontâneo à época da pesquisa (o índice alcança 65\% no conjunto de leitores com nível superior). Dentre os livros lidos nos últimos 3 meses pelos leitores entrevistados, $44 \%$ dos títulos tinham sido indicados pela escola; os didáticos correspondiam a $77 \%$ do total indicado.

Os meios em papel ainda permanecem como suporte preferencial para leitura no Brasil, embora perceba-se um declínio. A revista é primeira opção de leitura (53\%), os jornais (48\%), a segunda. O livro está em terceiro lugar, empatado com os livros indicados pela escola (47\%). Seguem-se as histórias em quadrinhos (30\%) e os textos escolares (24\%). Os textos na internet estão em quinto lugar ( $23 \%$ dos materiais lidos) e os livros digitais, em sétimo (4\%). Quanto ao tempo despendido semanalmente, o texto na internet ocupava em 2009 a primeira posição, consumindo em média $2 \mathrm{~h} 24 \mathrm{~min}$, enquanto o livro, na quinta posição, absorvia 1h56min dos leitores brasileiros (Amorim, 2009).

A despeito da importância do livro, grande contingente de brasileiros ainda se encontra excluído de seu universo, enquanto a digitalização avança. Se por um lado, a escolarização precária e a cultura de entretenimento brasileira apresentam-se como barreira para a leitura, por outro, novas gerações vêm aprendendo a ler diretamente nos meios digitais, sem antes conhecer ou mesmo manusear um livro comum - questões que reforçam a importância desta investigação.

Por isso, o estudo psicológico da leitura não deve limitar-se ao estudo dos processos de alfabetização e aprendizagem da leitura e da escrita. É preciso compreender a relação entre as transformações culturais e as alterações na estrutura de nossa percepção e experiência de leitura, as quais, por sua vez, modificam-se ao longo de nossa vida - não apenas durante os primeiros anos da escolarização (embora aí também sejam percebidos os efeitos destas transformações). Daí a necessidade de o psicólogo atentar para o papel desempenhado pela experiência leitura na formação do indivíduo e no desenvolvimento do sujeito.

Ao investigarmos a leitura enquanto experiência, buscamos enfatizar suas possibilidades e limites frente aos elementos que constituem esta leitura - o livro, a obra literária, suas formas de recepção -, oferecendo instrumentos para, sob uma perspectiva crítica, compor um campo de pesquisas em psicologia da leitura.

A leitura não se resume à compreensão de uma mensagem supostamente expressa. Isso porque a atividade de leitura ultrapassa a relação entre o leitor e o texto, sendo atravessada por um conjunto de elementos envolvidos em sua recepção. Como objeto mediador primeiro, o livro enquanto meio influi decisivamente nesse processo. Mas de que maneira o livro responde pelas qualidades da leitura?

\section{O estudo da experiência mediada em uma perspectiva crítica}

Dentre os estudos mais frequentemente utilizados para o estudo dos meios de comunicação, estão aqueles publicados pelo canadense Marshall McLuhan, em livros como A galáxia de Gutenberg [1962] e O meio é a mensagem [1967]. Os trabalhos de McLuhan centram-se na afirmação de que os meios de comunicação promovem modificações em nossos sentidos, alterando diretamente nossa percepção. Influiriam assim no modo como o homem recebe as informações e as transmite, acumula e utiliza o conhecimento. Para McLuhan, o isolamento da visão na cultura alfabética teria conduzido a novas formas de expressão mental, contribuindo para o declínio das culturas tradicionais orais, fundadas na audição como sentido. Separando pensamento e ação, a escrita teria sido responsável pela "destribalização" do homem, participando do advento da tridimensionalidade visual, estática, racional e sem emoção característica da 
modernidade (McLuhan, 1971). Diferente do que acontecia antes com a precária distribuição de manuscritos, mais "vistos" do que efetivamente lidos, a leitura linear e concentrada exigida pelo impresso teria contribuído decisivamente para o Renascimento cultural. O ponto fixo visual, necessário para a leitura do livro, conforma o pensamento e a percepção modernos, e seu uso teria se intensificado exatamente à época de Gutenberg.

Ainda que as considerações de McLuhan a respeito da influência do livro sobre a percepção sejam válidas, seu determinismo histórico e organicista na afirmação do poder da imprensa como fato isolado para a promoção de transformações históricas e culturais comprometem grande parte de suas assertivas.

De uma predominante análise dos conteúdos na esfera da comunicação abre-se espaço então para um estudo dos meios capaz de analisar categorias imanentes, mas não invariantes do objeto que medeia o produto cultural, em um fenômeno que não prescinde da experiência do receptor. Daí a opção em ancorar nossos estudos no campo da Teoria Crítica, quadro referencial no qual a experiência subjetiva, simultaneamente histórica e psicológica, aparece circunscrita, mas não determinada por uma certa estrutura perceptiva. No caso do livro, esta análise abarca necessariamente a relação entre a obra literária e o leitor. Considerando este quadro, antes de expor os resultados da pesquisa que constitui objeto deste artigo, apresentamos a seguir as categorias imanentes do livro (Dadico, 2012), brevemente descritas em uma perspectiva teórico-crítica.

\section{As categorias imanentes do livro}

O livro parece invisível para quem lê. Para compreendermos como o mediador atua, contudo, é preciso reconstituir suas características enquanto objeto. Longe de mostrar-se inerte, o livro atua como fetiche, mercadoria que o livro é. Lançando mão da ideia de que a mercadoria, ao ocultar seus elementos subjetivos, age sobre os indivíduos como se dispusesse de aspectos "mágicos", invisíveis, Adorno (2006a) propôs um método para desvendá-los inspirando-se na fisiognomia, ciência dos primeiros humanistas.

Os fisiognomonistas sustentavam a existência de uma correlação entre a aparência de uma pessoa e os atributos de seu caráter. Embora a fisiognomia tenha caído em descrédito como ciência (dado que os estados internos humanos encontram correspondente físico apenas em situações contingentes), desde que uma fenomenologia do objeto é possível a partir da descrição de seus elementos sensíveis, uma fenomenologia da mercadoria poderia evidenciar sua natureza de fetiche, mostrando como o objeto atua, em função de seu duplo caráter, isto é, também como sujeito, dotado de uma face humana passível de descrição. Daí a necessidade de um método adequado à investigação deste objeto híbrido, contraditório, objeto-sujeito, para o qual a fisiognomia tornava-se útil.

O método fisiognômico foi elaborado por Adorno (2006a) para auxiliá-lo em seus estudos sobre o rádio, que no início do século $X X$ tornava-se o primeiro grande meio de comunicação de massa. O impacto contundente do rádio levou os pesquisadores de então a preocuparem-se com os efeitos da nova tecnologia para a recepção e a produção cultural. Preocupações que não apenas mostraram-se legítimas, mas que constituem ainda hoje instrumentos valiosos para pensar o modo como as tecnologias da comunicação relacionam-se com a experiência do sujeito moderno.

Para entender as relações estabelecidas entre leitor e texto e delimitar o escopo do estudo sobre o livro, foi empregado o conceito de "campo fenomenal". O termo é utilizado por Adorno em seus estudos sobre o rádio com um sentido físico literal, uma vez que as ondas eletromagnéticas do rádio atingem o indivíduo no momento em que ele liga o aparelho. Em uma fisiognomia do livro, o uso do termo "campo" é utilizado em função de seu significado psicológico: o conceito de sociabilidade sincrética utilizado por Bleger (2011) permite entender que ao campo no qual se estabelece a relação entre duas pessoas (ainda que sem vínculo aparente em um mesmo espaço físico) corresponde a instituição de um outro espaço, não coincidente com aquele, e de contornos invisíveis, mas não menos concretos, onde estas relações se operam. Este fenômeno psicológico, descrito pela Psicologia Social, permite falar então de um campo fenomenal de leitura. Tratando-se de uma relação antropomorfizada, estabelecida entre leitor e livro, o conceito revela-se duplamente adequado, permitindo falar também de um sincretismo leitor-obra: fenômeno que instaura o espaço no qual se estabelecem as relações que tornam a leitura possível. Embora estas relações sejam invisíveis, elas são concretas, e envolvem tanto a percepção humana quanto elementos cognitivos e inconscientes que atravessam este campo. Tal estudo tornou possível elencar as categorias imanentes do livro presentes no campo fenomenal de leitura: a) a ilusão de proximidade; b) a conservação temporal; c) a multiplicidade gráfica; d) a semipadronização; e e) a unidade portabilidade-fluidez (Dadico, 2012). 
A ilusão de proximidade (a) leva o leitor a sentir-se próximo ao autor/narrador da obra, como se o texto tivesse sido escrito exclusivamente para ele. Esta categoria, mais ou menos intensificada pela obra, relaciona-se ao caráter individualizado do livro.

A conservação temporal (b) do livro contribui para ressaltar a unicidade da experiência de leitura, a despeito da padronização almejada pelo editor em busca de público. No caso específico do livro, esta padronização não pode ser alcançada de modo pleno, pois o leitor não é passivo na relação com o objeto - o livro depende de um esforço ativo do leitor para consumar a experiência que engendra. Embora o livro dependa de uma uniformidade linguística e de um público característico, ele não alcança uma massa de leitores, nem mesmo no caso dos best-sellers. O livro promove a padronização apenas até certo ponto: uma semipadronização (c).

A experiência de leitura do livro depende do leitor em um nível bastante superior àquela vinculada a meios como o rádio, o cinema ou a televisão, cuja recepção se dá de forma muito mais passiva. A pseudoindividuação de que falavam Adorno e Simpson em relação ao ouvinte da música popular, como correspondente da estandardização na esfera da produção musical (Carone, 2011), não encontra paralelo na experiência de leitura. A padronização alcançada pela obra literária é possível apenas do ponto de vista da linguagem e da forma do texto.

A multiplicidade gráfica (d), por sua vez, diz respeito à versatilidade do livro, que admite tanto a reprodução plástica quanto a literária. Uma pintura reproduzida no livro acarreta evidente prejuízo à experiência estética da imagem. Este prejuízo não é tão claro no caso da literatura. Necessário ressaltar, contudo, que essa "neutralidade" do livro é apenas aparente, na medida em que o livro em si acaba por constituir-se, ele mesmo, instrumento de acesso ao universo em que a obra literária é produzida, oferecendo informações desde a capa e projeto gráfico, adição de prefácios, orelhas, biografias e notas, estilo, tipo de papel até a quantidade de edições. Estas informações ajudam o leitor a localizar-se em relação ao universo de produção e reprodução da obra, mesmo que de forma dispersa.

Certos modos de ler livros correspondem às categorias expostas, atributos do livro. Ao materializar a "forma-conteúdo" da obra literária, o livro-texto - intermediário entre o objeto livro e o sujeito leitor -, enseja modos característicos de ler, descritos a seguir enquanto resultados da presente pesquisa. Estes resultados serão expostos por meio de uma breve apresentação das entrevistas de nossas leitoras: Leonor e de Rosa.
Antes de avançarmos, convém ressaltar que duas entrevistas não seriam capazes de constituir, obviamente, uma amostra representativa do conjunto dos leitores brasileiros. Contudo, a maneira como ambas as leitoras inserem-se no contexto cultural brasileiro enquanto leitoras e consumidoras de livros, bem como a riqueza de sua autopercepção ao ler, tornam-nas bastante ilustrativas das transformações presentes nos modos de ler livros verificadas no contexto de transição e digitalização da cultura em que vivemos.

As imagens que expressam os modos de ler livros que emergiram nas entrevistas de Leonor e Rosa foram destacadas no texto a seguir a fim de facilitar sua localização pelo leitor deste artigo.

\section{Relatos de leituras}

Leonor. Bestas povoam o livro Bestiario, de Cortázar (2007), escolhido por Leonor. O tema principal do livro, comum aos contos que o compõem, é a loucura, exatamente aquilo que desperta sua atenção para este livro:

... atrai essa coisa da loucura. Convivi com situações de gente doidinha mesmo, de conversar com gente que não está ali. [ ] Acho que essa fantasia pesadona do Cortázar me atrai um pouco. Nesse conto, tem uma carta... O autor vai tomar conta dessa casa, e aí começam a proliferar coelhinhos, coelhinhos brancos dentro do apartamento. Aí ele foi achando bonitinho, e deixando. [ ] Tinha os doidinhos da família, tinha os doidinhos de esquizofrenia braba da moradia [ ]. Isso é uma coisa com que convivi desde a infância e ficava impressionada.

Como percebemos no seu relato, embora a loucura atraia a atenção de Leonor para o livro, a posição que ela assume é de alguém que observa o problema de um ponto de vista externo, ainda que próximo: o homem perante a natureza. Nesse sentido, o livro possibilita a Leonor, por meio de uma identificação com os personagens dos contos, a experiência de alguém que pode ver-se às voltas com a questão, como nos contos "Lejana" ("Distante", em espanhol) e "Bestiario" (Cortázar, 2007), sem provar diretamente da loucura. A experiência de leitura é intensa, porém, de modo que o tigre do conto "Bestiario", fera que ronda a casa dos personagens, acaba por adquirir "um significado simbólico, imaginar que nas casas têm tigres andando para lá e para cá", como ela descreve, e passa a figurar nos próprios sonhos da leitora. 
Leonor identifica-se claramente, como ela enuncia, com alguns personagens dos contos - Alina, Clara, Rema. A identificação subjetiva (a) caracteriza seu modo de ler. Mas, ao mesmo tempo, ela pode falar a respeito dessas histórias a partir de um referencial externo, que denominamos ponto de fuga (b). O ponto de fuga é constituído pelas diversas posições a partir do qual se estabelece a perspectiva da leitora perante a história, com seus planos variados, bem como o espaço ao qual ela retorna quando a imersão na história torna-se emocionalmente excessiva.

Desde o início, Leonor estabelece juízos sobre o livro, o autor, a história: sua experiência não é ingênua. Esses juízos formam-se a partir do contato com as leituras de terceiros, de um texto introdutório ou da simpatia que o texto em si angaria durante a leitura. O ponto de fuga entrelaça-se, assim, aos juízos da leitora, possibilitando-lhe imergir na história e identificar-se de forma mais absoluta e menos inconsciente com certos personagens da trama, por meio de um modo de leitura intensivo (c), sem, contudo expor-se ao risco de fazer como leitores de outrora, que chegavam a responder à leitura com o suicídio.

Desta maneira, o leitor pode "localizar-se" em relação à obra, movimentando-se de acordo com suas próprias necessidades e interesses. Ele "entra" na obra da forma o mais visceral possível, mas busca, simultaneamente, salvaguardar-se enquanto sujeito, esforçando-se por "destacar-se" criticamente dela. A possibilidade de compartilhar posteriormente a experiência de ler exerce papel importante no modo de leitura caracterizado pelo ponto de fuga.

A relação que Leonor estabelece com a obra se dá por via de seus conteúdos, apesar de ela ter lido o livro em língua original (espanhol). Aspectos formais que poderiam ajudá-la a aproximar-se de algumas das questões propostas pelo autor diluem-se sob o guarda-chuva do "realismo fantástico", chave que reúne as pistas interpretativas utilizadas por ela. No processo em que o livro e o texto desaparecem de sua visão para dar lugar à obra mesma, são as imagens descritas por Leonor que oferecem escape à leitura conteudística (d), trazendo o estranho como contraste à regularidade cotidiana dos enredos.

Rosa. Rosa é atraída pela primeira página do livro que escolhe ler. Ali, o narrador em primeira pessoa já se apresenta como assassino. A identificação subjetiva, como modo de ler de Rosa, logo vem à tona, relacionada ao narrador-protagonista. Ela mesma fornece as razões para tanto: também se sente culpada de um grave delito. Ainda que, na história pessoal de Rosa, ela figurasse mais como vítima do que transgressora, a ambiguidade das situações que viveu contribui para esta sua leitura. À imagem do crime, o assassinato presente no livro escoIhido, corresponde a ideia de uma "reparação", título de um terceiro romance, lido em outra ocasião. A reparação impossível na história a que se refere este terceiro título torna-se a imagem que expressa as feridas abertas na vida de Rosa. A leitura de Reparação (McEwan, 2011), atravessa então, de forma pungente, a leitura de $O$ pintor de pássaros (Norman, 1997), que ela escolheu discutir conosco.

Se por um lado, a leitura de Rosa é enriquecida pela diversidade de aspectos qualitativos que ela consegue descrever, compreender e explicar criticamente, por outro, percebe-se que os elementos que compõem o livro, articulados de forma frágil, prejudicam o "efeito de real" não nomeado, mas esperado por Rosa. Isto frustra a experiência estética de Rosa, limitada não por sua capacidade de abrir-se ao universo da obra e atentar para os aspectos formais do romance, mas pela qualidade artística do material. As limitações estéticas do livro tornam-se impossibilidade: seu enredo comove menos do que a tragédia vivida pela própria leitora.

Rosa lê tanto intensiva quanto extensivamente. Sua casa exibe livros em grande quantidade, apesar de uma boa parte de sua biblioteca ter sido já distribuída entre os filhos. Rosa efetivamente os lê, a despeito de um problema de visão que avança com a idade, percorrendo textos com fome de ler (e) - termo inaugurado por Baker e Escarpit (1975). Interessante notar que, se por um lado, essa "fome" possibilita a Rosa ler grande quantidade de livros, abrindo-se a tantas experiências literárias, por outro ela acaba, junto à habilidade que ela constrói de localizar com rapidez nas obras os elementos que a interessam, por compeli-la a uma leitura distraída (f), interrompida (g) por tantos vais-e-vens, e atomística (h) - modos de ler que prejudicam sua capacidade de ler um livro inteiro.

Rosa salta trechos, não raro lê antes o final do livro do que o começo. Se esse salto não oferece boa promessa, Rosa abandona o que está lendo ou não se compromete com o livro. Sobre seu criado-mudo acumulam-se títulos aos quais ela se dedica simultaneamente, cuja leitura talvez ela nunca conclua. 


\section{Modos de ler e experiências de leitura}

Acompanhando a ordem segundo a qual despontam nos relatos acima, é possível reconhecer nas entrevistas os seguintes modos de ler: a) a identificação subjetiva; b) o ponto de fuga; c) o modo intensivo; d) a leitura conteudística; e) a fome de ler; f) a leitura distraída; g) a leitura interrompida; e h) a leitura atomística.

A identificação subjetiva (a), como modo de ler livros, dialoga a psicanálise freudiana, mas não pode ser totalmente explicada a partir dela. Na teoria freudiana, a identificação corresponde à internalização de um objeto externo, uma figura de autoridade, como o pai, que representa para o sujeito as normas da sociedade, como interveniência do supereu na constituição da personalidade (Freud, 2011). No âmbito da cultura, o sujeito pode encontrar figuras variadas que atuam como modelo para o ajustamento à sociedade, que ultrapassam seu círculo de relações diretas, como as familiares, bem como as questões psicossexuais que Ihe são inerentes. Quando se trata de produtos oferecidos pela indústria cultural, verifica-se que estes modelos estão voltados a uma padronização das necessidades dos consumidores. Por isso, a identificação com eles promove não o desenvolvimento subjetivo, mas uma "desindividualização", que atinge a razão e a subjetividade de forma articulada. Por um lado, ideologia e racionalidade técnica impõem-se sob a forma de conceitos que se substituem ao pensamento, sacrificando a multiplicidade qualitativa da experiência. Por outro lado, o sujeito é assimilado à totalidade social por meio da identificação. Reportando o eu ao social, esse processo acaba por solapar a autonomia do indivíduo (Adorno, 2006b). A despeito dos pesados sacrifícios pulsionais impostos pelo supereu, o sujeito, tragicamente, não consegue ser feliz em sociedade, nem escapar dela. Tem-se então um "extravasamento" do indivíduo obliterado durante a recepção da obra, processo por meio do qual o sujeito "expulsa de si e localiza no exterior qualidades, sentimentos e desejos próprios" (Rouanet, 2010, p.14).

No caso da leitura de livros, conforme pontuado no relato de Leonor, o ponto de fuga (b) oferece um contraponto aos efeitos e condicionantes da identificação subjetiva como modo de ler. O leitor pode então encontrar pontos de apoio diversos para sua recepção, deslocando-se no interior da obra a fim de apreender seus aspectos plurais - para o que concorre a identificação subjetiva e seus múltiplos objetos.
Importante destacar que a forma do livro exerce um papel importante na configuração destes modos de leitura. Enquanto a identificação subjetiva é favorecida pela ilusão de proximidade, como categoria imanente do livro, o ponto de fuga é favorecido pela conservação temporal do livro. Isto porque, na medida em que o livro propicia uma recepção temporalmente distendida, a experiência de leitura desdobra-se no tempo, guardando certa autonomia em relação ao objeto. Mais ajustada aos ritmos individuais e da própria obra do que ao ritmo da máquina (no caso dos meios eletrônicos, por exemplo), a distensão possível durante a leitura do livro favorece uma recepção refletida, nutrida pela experiência do leitor e capaz de dialogar com valores, história e realidade circunstante, tanto aqueles próprios do leitor quanto aqueles percebidos na obra.

A forma atual do livro também contribui para a promoção de uma leitura distraída (f), interrompida (g), atomística (h) e conteudística (d). Isso porque a disposição homogênea do texto, com tipos uniformes, letras pequenas e pouco distanciamento entre as palavras contribui para que o leitor esqueça-se do objeto que tem em mãos. A aparente neutralidade do objeto faz com que o leitor se concentre, primeiramente, não no livro, mas no impresso, e em seguida, não mais no texto - cuja paginação estimula uma leitura fluída - e nas formas textuais, mas no conteúdo da obra. A leitura conteudística (d) dificulta a apreensão estrutural da obra como forma-conteúdo, o que reduz o alcance da leitura, limitando a própria obra e seu universo. Segundo Adorno, as formas e os conteúdos de uma obra compõem uma unidade [Gehalt] capaz de expressar sua ideia e significados. Para alcançar o conteúdo de verdade [Wahrheitsgehalt] desta obra, é preciso que o leitor possa descrevê-la, compreendê-la e explicá-la criticamente (Adorno citado por Goldmann, 1975). Daí a emergência do elo que aproxima o universo do leitor do universo da obra, e vice-versa, recuperando os sentidos da obra no presente - elo que se enfraquece perante o conjunto de leituras fragmentadas listado.

Em meio ao "circuito de distrações" gerado pelo livro, a leitura distraída (f) desponta, de forma relevante, tornando o leitor menos autônomo e responsável pelo controle de seu próprio ritmo e qualidade da leitura. Contudo, tanto a leitura distraída quanto a leitura interrompida e atomística não constituem necessariamente modos "negativos" de se ler um livro. A distração pode, por exemplo, contribuir para 
que o pensamento interponha-se à leitura durante o afastamento temporário do material, desde que o livro autorize o retorno do leitor à obra. Eventualmente, é a leitura interrompida que nos permite ler uma obra mais longa, e a leitura atomística quem nos auxilia a compreender o significado de uma passagem mais difícil. Consideramos neste artigo o significado destes modos de leitura para nossas leitoras em particular, destacando que, para Rosa, a leitura saltada de trechos "atomizados" tem para ela o paradoxal objetivo de levá-la a compreender a obra em seus aspectos estruturais.

Os modos de ler que relacionamos tornam-se problemáticos na medida em que impõem limites ao leitor, isto é, quando tornam-se modos de ler cristalizados, que solapam seus esforços na direção de uma leitura mais intensiva, por exemplo.

Se os modos de leitura são influenciados não apenas pela forma do livro, mas também pela experiência que estrutura uma certa leitura, estes três modos de ler em particular - a leitura distraída, interrompida e atomística - podem ser mais fortemente relacionadas ao modo como nossa percepção organiza-se, em nossos dias, para a vivência nas grandes cidades, em prontidão para o choque (Benjamin, 1994). Particularmente no que se refere à leitura atomística (h), pode-se já perceber a influência da digitalização da cultura na conformação de uma leitura do texto tratado exclusivamente como informação.

Antes de passar às considerações finais deste artigo, convém mencionar que tanto a fome de ler (e) quanto o modo intensivo (c) de leitura persistem caracterizando o modo de ler livros atual como eco de períodos anteriores, típicos da segunda e da primeira revoluções da leitura. A fome de ler, particularmente importante durante o Romantismo, coaduna-se mais estreitamente com a formação cultural de Rosa, enquanto a leitura intensiva - neste caso mais analítica do que devotada corresponde bastante fielmente à tradição acadêmica que dialoga com a educação de Leonor.

\section{Considerações finais: A leitura como experiência}

No contexto de uma terceira revolução da leitura, é possível identificar características da experiência de leitura que se cristalizam em modos de ler específicos e usos do livro de papel: a) a identificação subjetiva; b) o ponto de fuga; c) o modo intensivo; d) a leitura conteudística; e) a fome de ler; f) a leitura distraída; g) leitura interrompida; h) leitura atomística. Alguns desses modos de ler conservam gestos comuns às diversas funções que a leitura de livros já assumiu em sua história - como a leitura intensiva, por exemplo. Modos de ler que seguem relevantes no presente. Outros apresentam-se como tendência, sinalizando modos novos de se ler - como a leitura atomística -, os quais certamente serão melhor compreendidos no momento em que houverem mais estudos disponíveis sobre a leitura de livros em meios digitais. Interessante notar como estas tendências aparecem já contidas tanto no formato do livro em papel, quanto em seus usos. É o caso da leitura distraída, que se relaciona fortemente com a paginação homogênea dos livros, mas que também expressa um aspecto importante da experiência moderna, marcada, por exemplo, pela multiplicidade de estímulos e atividades simultâneas que aprendemos a realizar, hábito ainda mais acentuado no contexto das novas mídias. Lembrando que a distração constitui um problema fundamental nas discussões sobre a experiência empreendidas por Walter Benjamin.

No que se refere à articulação entre a leitura de livros e a experiência do leitor, é importante frisar que a ideia de experiência benjaminiana reporta-se tanto à história individual quanto à história da cultura, de forma dialética.

No Brasil, notamos que não apenas os modos de ler que elencamos em nossa pesquisa, mas os próprios dados estatísticos que comparecem nos levantamentos sobre hábitos de leitura do brasileiro refletem nossa segmentação social e a desvalorização social da leitura de livros enquanto experiência. Esta desvalorização se reflete, por exemplo, na dificuldade que as leitoras relataram encontrar para compartilhar suas experiências de leituras com outras pessoas, e em uma tendência para "dar notícias" sobre uma obra literária que muitas vezes sequer foi lida.

Arriscando um prognóstico, é possível que esta questão atrase a passagem do livro do papel para os meios digitais no país, ao mesmo tempo em que o brasileiro venha a se tornar mais velozmente aderente a novos instrumentos de mediação do livro, minando modos de ler outrora construídos e mostrando-se propenso à adoção de modos de ler radicalmente novos. Isto aliado ao risco de ver-se mais intensamente às voltas com a crise da leitura que ameaça a leitura de livros no contexto de sua terceira revolução.

Por fim, gostaríamos de destacar que a unidade que a obra literária apresenta mais facilmente ao ser mediada pelo livro favorece sua apreensão estrutural, ao mesmo tempo em que a leitura conteudística é nutrida pelo mesmo objeto. Em comparação com outros meios de comunicação que conhecemos, o livro, com suas categorias imanentes, confere maior autonomia aos leitores e engendra uma experiência de leitura 
distendida no tempo e no espaço. Isto favorece a alternância entre identificação subjetiva e ponto de fuga, facilitando os deslocamentos pela obra que a experiência estético-literária propicia, bem como o diálogo efetivo entre os universos da obra e do leitor. Diálogo este que constitui elemento fundamental nas passagens entre experiência de leitura, formação do indivíduo e desenvolvimento do sujeito.

\section{Referências}

Adorno, T.W. (2003). Notas de literatura I. São Paulo: Duas Cidades/ Editora 34.

Adorno, T.W. (2006a). Current of music: elements of a Radio Theory. Frankfurt: Suhrkamp.

Adorno, T.W. (2006b). Teoria estética. Lisboa: Edições 70.

Amorim, G. (Org.) (2009). Retratos da leitura no Brasil. São Paulo: Imprensa Oficial/Instituto Pró-livro.

Barker, R., \& Escarpit, R. (1975). A fome de ler. Rio de Janeiro: Fundação Getúlio Vargas/Instituto Nacional do Livro.

Benjamin, W. (1994). Charles Baudelaire: um lírico no auge no capitalismo ( $3^{\underline{a}}$ ed.). São Paulo: Brasiliense.

Bleger, J. (2011). Temas de Psicologia: entrevista e grupos. São Paulo: Martins Fontes.

Carone, I. (2011). A face histórica de "On Popular Music". Revista Constelaciones de Teoria Critica, 3, 148-178.

Cavallo, G., \& Chartier, R. (1995). Storia della lettura nel mondo occidentale. Bari: Editori Laterza.

Cortázar, J. (2007). Bestiario (2ª ed.). Buenos Aires: Punto de Lectura.

Dadico, L. (2011). Flaubert e o crepúsculo do sujeito: uma análise do conto "Um coração simples". Psicologia USP, 22(3), 655-680. doi: $10.1590 /$ S0103-65642011005000021
Dadico, L. (2012). A "fisiognomia" do livro no estudo psicológico da leitura. Psicologia em Estudo, 17(4), 629-638. doi: 10.1590/S141373722012000400009

Darnton, R. (2011). O grande massacre dos gatos: e outros episódios da história cultural francesa. Rio de Janeiro: Graal.

Freud, S. (2011). Neurose e psicose. In S. Freud (Org.), Obras completas, volume 16: o eu, o id, "autobiografia" e outros textos (1923-1925) (pp. 176-183). São Paulo: Companhia das Letras.

Goldmann, L. (1975). Discussion extraite des actes du second colloque international sur la sociologie de la littérature tenu à Royaumont, par L. Goldmann et Th.-W. Adorno. In L. Goldmann (Org.), Lucien Goldmann et la sociologie de la littérature: hommage à Lucien Goldmann. Bruxelles: Éditions de l'Université de Bruxelles.

Hallewell, L. (2005). O livro no Brasil:sua história. São Paulo: Editora da Universidade de São Paulo.

Instituto Brasileiro de Geografia e Estatística (2012). Pesquisa nacional de amostra de domicílios. Recuperado de ftp://ftp.ibge.gov.br/ Trabalho_e_Rendimento/Pesquisa_Nacional_por_Amostra_de_ Domicilios_anual/2012/Sintese_Indicadores/sintese_pnad2012.pdf

Instituto Pró-Livro (2012). II seminário nacional retratos da leitura no Brasil, Brasília-DF. Recuperado de http://www.prolivro.org.br/ipl/ publier4.0/dados/anexos/2834_10.pdf .

McEwan, I. (2011). Reparação. São Paulo: Companhia das Letras.

McLuhan, M. (1971). O meio é a mensagem. São Paulo: Companhia Editora Nacional.

Moretti, F. (2003). O século sério. Novos Estudos, 65, 3-33. Recuperado de http://novosestudos.uol.com.br/v1/contents/view/1036

Norman, H. (1997). O pintor de pássaros. Rio de Janeiro: Rocco.

Queiróz, M. I.P.(1983). Variações sobre a técnica de gravador no registro da informação viva. São Paulo: CERU/FFLCH.

Rouanet, S. P. (2010). Adorno e a crítica da barbárie: Um olhar psicanalítico. In J. C. Soares (Org.), Escola de Frankfurt: inquietudes da razão e da emoção (pp. 11-24). Rio de Janeiro: EDUERJ.

\footnotetext{
${ }^{1}$ O projeto que deu ensejo a esta pesquisa foi aprovado pelo Comitê de Ética em Pesquisa com Seres Humanos do Instituto de Psicologia da Universidade de São Paulo em ofício No. 102/2010, em 22/10/2010.

${ }^{2}$ A palavra alemã Gehalt, frequentemente traduzida para o português como "teor", não é sinônimo da palavra Inhalt, ou "conteúdo". Localizando-se entre Inhalt e Gestalt ("forma"), o termo alemão permite imediatamente compreender a ideia de "forma-conteúdo" que Adorno considera fundamento da análise imanente. (Adorno, 2003).

${ }^{3}$ Critério do IBGE para "analfabetismo funcional".

${ }^{4}$ Esse dado mostra que à metade de leitores corresponde uma metade de não leitores: isto é, cerca 88,2 milhões de brasileiros não têm o hábito de ler livros. O número de leitores no Brasil vem caindo nos últimos anos, a despeito da melhoria geral das condições econômicas da população.
}

Luciana Dadico, Doutora em Psicologia Escolar, da Aprendizagem, do Desenvolvimento e da Personalidade pelo Instituto de Psicologia da USP, pós-doutora junto ao Programa de Teoria Crítica da Universidade da Califórnia, Berkeley, é pós-doutoranda junto ao Instituto de Psicologia da USP com financiamento da Fundação de Amparo à Pesquisa do Estado de São Paulo (FAPESP). Endereço para correspondência: Av. Brig. Luís Antonio, 388, cj.91 - Bela Vista - São Paulo/SP. CEP 01318-000. E-mail: ludadico@usp.br 